University of Nebraska - Lincoln

DigitalCommons@University of Nebraska - Lincoln

\title{
Effects of Mining-Derived Metals on Riffle-Dwelling Crayfish in Southwestern Missouri and Southeastern Kansas, USA
}

Ann L. Allert

United States Geological Survey, aallert@usgs.gov

Robert J. DiStefano

Central Regional Office and Conservation Research Center

Christopher J. Schmitt

United States Geological Survey, cjschmitt@usgs.gov

James F. Fairchild

United States Geological Survey, jfairchild@usgs.gov

William G. Brumbaugh

United States Geological Survey, bbrumbaugh@usgs.gov

Follow this and additional works at: https://digitalcommons.unl.edu/usgsstaffpub

Allert, Ann L.; DiStefano, Robert J.; Schmitt, Christopher J.; Fairchild, James F.; and Brumbaugh, William G., "Effects of Mining-Derived Metals on Riffle-Dwelling Crayfish in Southwestern Missouri and Southeastern Kansas, USA" (2012). USGS Staff -- Published Research. 530.

https://digitalcommons.unl.edu/usgsstaffpub/530

This Article is brought to you for free and open access by the US Geological Survey at DigitalCommons@University of Nebraska - Lincoln. It has been accepted for inclusion in USGS Staff -- Published Research by an authorized administrator of DigitalCommons@University of Nebraska - Lincoln. 


\title{
Effects of Mining-Derived Metals on Riffle-Dwelling Crayfish in Southwestern Missouri and Southeastern Kansas, USA
}

\author{
Ann L. Allert • Robert J. DiStefano • \\ Christopher J. Schmitt • James F. Fairchild • \\ William G. Brumbaugh
}

Received: 27 April 2012/ Accepted: 31 July 2012/Published online: 8 September 2012

(C) Springer Science+Business Media, LLC (outside the USA) 2012

\begin{abstract}
Riffle-dwelling crayfish populations were sampled at 16 sites in 4 tributaries of the Spring River located within the Tri-State Mining District in southwest Missouri. Crayfish density, physical habitat quality, and water quality were examined at each site to assess the ecological effects of mining-derived metals on crayfish. Metals (lead, zinc, and cadmium) were analyzed in samples of surface water, sediment, detritus, and whole crayfish. Sites were classified a posteriori into reference, mining, and downstream sites primarily based on metal concentrations in the materials analyzed. Three species of crayfish (Orconectes neglectus neglectus, $O$. macrus, and $O$. virilis) were collected during the study; however, only $O$. n. neglectus was collected at all sites. Mean crayfish densities were significantly lower at mining sites than at reference sites. Mean concentrations of metals were significantly correlated among the materials analyzed and were significantly greater at mining and downstream sites than at reference sites. Principal component analyses showed a separation of sites due to an inverse relationship among crayfish density, metals concentrations, and physical habitat quality variables. Sediment probable-
\end{abstract}

Electronic supplementary material The online version of this article (doi:10.1007/s00244-012-9797-9) contains supplementary material, which is available to authorized users.

A. L. Allert $(\varangle) \cdot$ C. J. Schmitt · J. F. Fairchild

W. G. Brumbaugh

Columbia Environmental Research Center,

United States Geological Survey, 4200 New Haven Road,

Columbia, MO 65201, USA

e-mail: aallert@usgs.gov

R. J. DiStefano

Missouri Department of Conservation,

Central Regional Office and Conservation Research Center,

3500 East Gans Road, Columbia, MO 65201, USA effects quotients and surface-water toxic unit scores were significantly correlated; both indicated risk of toxicity to aquatic biota at several sites. Metals concentrations in whole crayfish at several sites exceeded concentrations known to be toxic to carnivorous wildlife. Mining-derived metals have the potential to impair ecosystem function through decreased organic matter processing and nutrient cycling in streams due to decreased crayfish densities.

The Tri-State Mining District (TSMD) occupies an area of approximately 647,500 ha in southwestern Missouri, southeastern Kansas, and northeastern Oklahoma. The TSMD was mined for zinc $(\mathrm{Zn})$ and lead $(\mathrm{Pb})$ for $>150$ years, beginning in the mid-1800s and ending in the late 1960s, with peak production occurring during World War II (Stewart 1986). Many sites in the TSMD are contaminated by wastes from historical mining, ore processing, and smelting (Barks 1977; Czarnezki 1985; Davis and Schumacher 1992), which has resulted in effects on aquatic organisms and potential risk to humans and wildlife (Angelo et al. 2007; Brumbaugh et al. 2005; MacDonald et al. 2010; Schmitt et al. 2006; Wang et al. 2010; Wildhaber et al. 1997, 2000). The United States Environmental Protection Agency (USEPA) has established four Superfund National Priority List (NPL) sites within the TSMD.

Crayfish are an important structural component of many aquatic systems, including Ozark streams, where they have been found to be the predominant macroinvertebrate (Rabeni 1985). Crayfish also play an integral role in stream function and the cycling of nutrients and energy through stream food webs by shredding organic matter (Creed 1994; Momot et al. 1978; Momot 1995; Rabeni et al. 1995) and as an important prey item for fish and other aquatic and terrestrial vertebrates (DiStefano 2005 and references 
therein; Hobbs 1993; Rabeni et al. 1995). Recent research has showed that crayfish significantly affect aquatic microhabitats by way of ecosystem engineering (Zhang et al. 2004). Therefore, effects on crayfish may result in changes in the structure and function of Ozark stream ecosystems.

The objectives of this study were to determine crayfish species composition and densities in riffle habitats at selected stream sites in the TSMD; to evaluate crayfish densities relative to concentrations of the mining-derived metals, $\mathrm{Pb}, \mathrm{Zn}$, and cadmium $(\mathrm{Cd})$, in surface water, sediment, detritus, and whole crayfish; to characterize physical habitat and water quality; and to evaluate the potential effects of metals in crayfish to carnivorous wildlife.

\section{Materials and Methods}

Crayfish were sampled in riffle habitats of tributaries of the Spring River of southwestern Missouri and southeastern Kansas. The 16 sample sites were located in Jenkins Creek, Center Creek, Turkey Creek, and Shoal Creek (Table 1; Fig. 1). Sites were selected based on stream order (Strahler 1952) and proximity to areas with mine waste. Sites were classified based on distances downstream from known sources of mining-related contaminants and metal concentrations in the materials analyzed from each site. Sites considered upstream of contaminated areas where metals concentrations were low (e.g., reference sites) included J1, $\mathrm{C} 1, \mathrm{~T} 1, \mathrm{~T} 2, \mathrm{~S} 1$, and $\mathrm{S} 2$; sites directly downstream of highly contaminated areas where metals concentrations were high (e.g., mining sites) included C2, C3, C4, T3, S3, and S6; and sites considered to be further downstream of mining or less contaminated areas where metals concentrations were intermediate (e.g., downstream sites) included C5, T4, S4, and S5.

Crayfish were collected by disturbing the substrate inside a $1 \mathrm{~m}^{2}$ weighted polyvinyl chloride (PVC) quadrat frame placed on the stream bottom directly upstream of a kick seine $(1.5 \mathrm{~m}$ length $\times 1.5 \mathrm{~m}$ height $)$ with a $3 \mathrm{~mm}$ diameter delta mesh on one date per site during the period of July 13 to 29, 2009 (15 sites) or on September 3, 2009 (Site S6). Each site consisted of a stream reach containing three riffles. Eight kick-seine subsamples were randomly located in each riffle (total $n=24 /$ site). Crayfish were identified as to species (Pfleiger 1996), and carapace length (CL) was measured (to the nearest $0.1 \mathrm{~mm}$ ) from the tip of rostrum to the posterior edge of the cephalothorax. All crayfish except those retained for metal analyses were released alive to the stream.

Table 1 Sampling locations in Jenkins, Center, Turkey, and Shoal creeks in southwestern Missouri and southeastern Kansas, USA

\begin{tabular}{|c|c|c|c|c|c|c|c|c|c|}
\hline $\begin{array}{l}\text { Stream/ } \\
\text { site }\end{array}$ & Latitude & Longitude & $\begin{array}{l}\text { Gradient } \\
(\mathrm{m} / \mathrm{km})\end{array}$ & $\begin{array}{l}\text { Drainage } \\
\text { area (ha) }\end{array}$ & $\begin{array}{l}\text { Upstream } \\
\text { tailings } \\
\text { area (ha) }\end{array}$ & $\begin{array}{l}\text { Tailings } \\
\text { area/ } \\
\text { drainage } \\
\text { area }\end{array}$ & $\begin{array}{l}\text { Distance } \\
\text { downstream } \\
\text { from tailings }(\mathrm{km})\end{array}$ & $\begin{array}{l}\text { Stream } \\
\text { order }\end{array}$ & $\begin{array}{l}\text { Site } \\
\text { group }\end{array}$ \\
\hline \multicolumn{10}{|c|}{ Jenkins creek } \\
\hline $\mathrm{J} 1$ & $37^{\circ} 04^{\prime} 33.4^{\prime \prime}$ & $94^{\circ} 15^{\prime} 40.1^{\prime \prime}$ & 5.01 & 9,324 & 0.70 & 0.00008 & 5.1 & 3 & $\mathrm{R}$ \\
\hline \multicolumn{10}{|c|}{ Center creek } \\
\hline $\mathrm{C} 1$ & $37^{\circ} 06^{\prime} 46.9^{\prime \prime}$ & $94^{\circ} 18^{\prime} 02.9^{\prime \prime}$ & 4.36 & 29,526 & 27.8 & 0.00094 & 15 & 5 & $\mathrm{R}$ \\
\hline $\mathrm{C} 2$ & $37^{\circ} 10^{\prime} 46.6^{\prime \prime}$ & $94^{\circ} 27^{\prime} 56.2^{\prime \prime}$ & 2.52 & 66,045 & 588 & 0.00891 & 3.4 & 5 & $\mathrm{M}$ \\
\hline $\mathrm{C} 3$ & $37^{\circ} 10^{\prime} 04.6^{\prime \prime}$ & $94^{\circ} 32^{\prime} 21.3^{\prime \prime}$ & 2.52 & 67,340 & 785 & 0.01166 & 0.6 & 5 & M \\
\hline $\mathrm{C} 4$ & $37^{\circ} 10^{\prime} 45.8^{\prime \prime}$ & $94^{\circ} 28^{\prime} 44.7^{\prime \prime}$ & 2.46 & 73,297 & 815 & 0.01112 & 3.9 & 5 & M \\
\hline C5 & $37^{\circ} 09^{\prime} 05.4^{\prime \prime}$ & $94^{\circ} 36^{\prime} 50.7^{\prime \prime}$ & 2.72 & 77,182 & 908 & 0.01176 & 1.0 & 5 & $\mathrm{D}$ \\
\hline \multicolumn{10}{|c|}{ Turkey creek } \\
\hline $\mathrm{T} 1$ & $37^{\circ} 05^{\prime} 24.1^{\prime \prime}$ & $94^{\circ} 27^{\prime} 27.9^{\prime \prime}$ & 8.98 & 4,144 & 81.7 & 0.01971 & 2.7 & 2 & $\mathrm{R}$ \\
\hline $\mathrm{T} 2$ & $37^{\circ} 06^{\prime} 38.4^{\prime \prime}$ & $94^{\circ} 31^{\prime} 17.2^{\prime \prime}$ & 3.66 & 6,734 & 143 & 0.02128 & 4.1 & 3 & $\mathrm{R}$ \\
\hline $\mathrm{T} 3$ & $37^{\circ} 06^{\prime} 51.6^{\prime \prime}$ & $94^{\circ} 32^{\prime} 44.9^{\prime \prime}$ & 3.63 & 9,324 & 225 & 0.02417 & 1.1 & 4 & M \\
\hline $\mathrm{T} 4$ & $37^{\circ} 07^{\prime} 46.9^{\prime \prime}$ & $94^{\circ} 37^{\prime} 35.2^{\prime \prime}$ & 4.79 & 11,396 & 318 & 0.02790 & 4.5 & 4 & $\mathrm{D}$ \\
\hline \multicolumn{10}{|c|}{ Shoal creek } \\
\hline S1 & $36^{\circ} 56^{\prime} 34.7^{\prime \prime}$ & $94^{\circ} 18^{\prime} 03.9^{\prime \prime}$ & 3.36 & 69,671 & 96.0 & 0.00138 & 6.8 & 5 & $\mathrm{R}$ \\
\hline S2 & $37^{\circ} 01^{\prime} 25.7^{\prime \prime}$ & $94^{\circ} 31^{\prime} 11.0^{\prime \prime}$ & 2.84 & 84,952 & 120 & 0.00142 & 5.1 & 5 & $\mathrm{R}$ \\
\hline S3 & $37^{\circ} 02^{\prime} 07.7^{\prime \prime}$ & $94^{\circ} 35^{\prime} 16.5^{\prime \prime}$ & 1.52 & 113,441 & 181 & 0.00160 & 2.6 & 5 & M \\
\hline S4 & $37^{\circ} 02^{\prime} 24.0^{\prime \prime}$ & $94^{\circ} 36^{\prime} 30.1^{\prime \prime}$ & 2.32 & 114,736 & 209 & 0.00182 & 2.4 & 5 & $\mathrm{D}$ \\
\hline S5 & $37^{\circ} 02^{\prime} 31.2^{\prime \prime}$ & $94^{\circ} 39^{\prime} 08.0^{\prime \prime}$ & 3.08 & 116,549 & 213 & 0.00183 & 7.1 & 5 & $\mathrm{D}$ \\
\hline S6 & $37^{\circ} 02^{\prime} 33.8^{\prime \prime}$ & $94^{\circ} 39^{\prime} 23.6^{\prime \prime}$ & 3.08 & 117,585 & 345 & 0.00294 & 0.5 & 5 & M \\
\hline
\end{tabular}

$R$ reference site, $M$ mining site, $D$ downstream site 
Fig. 1 Study sites, mine-related waste (i.e., chat piles), city of Joplin boundary, and designated areas within USEPA NPL (Superfund) sites, as well as drainages, which are distinguished by gray shades

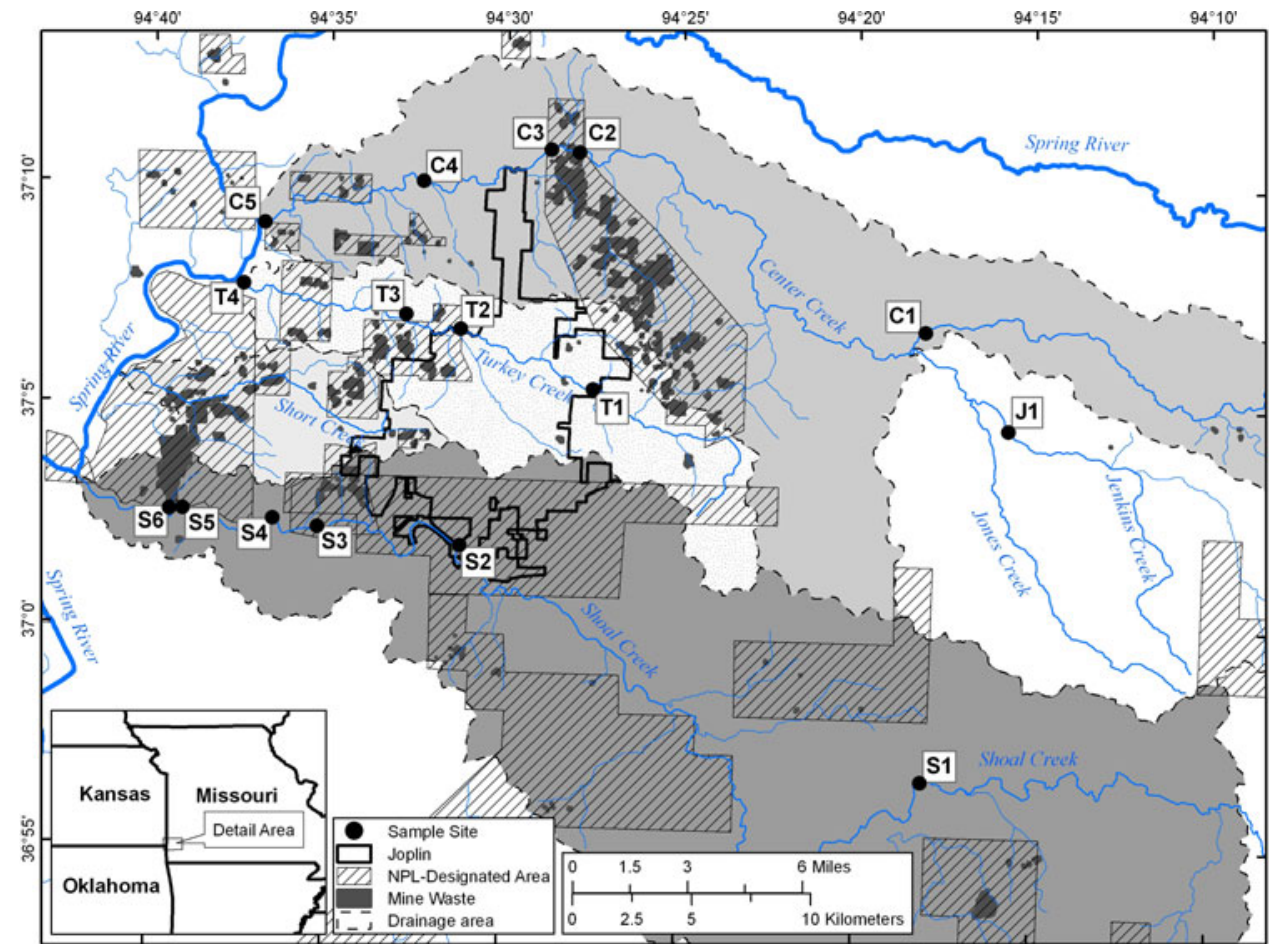

Water depth and current velocity were measured at each $1 \mathrm{~m}^{2}$ kick-seine quadrat just before crayfish sampling using a Marsh-McBirney 2000 portable flow meter (Hach Inc., Loveland, Colorado, USA) at 6/10 of measured depth (Bain and Stevenson 1999). Substrate particle size was visually estimated at five random points within a $0.5 \times 0.5 \mathrm{~m}$ grid of each quadrat and assigned a value based on six coarseness categories (Bain et al. 1985).

A Hydrolab Quanta meter (Hach Inc., Loveland, Colorado, USA) was used to measure temperature, $\mathrm{pH}$, specific conductance, dissolved oxygen, and turbidity in each riffle sampled for crayfish. A surface-water grab sample was collected from each riffle for analyses of metals $(\mathrm{Pb}, \mathrm{Zn}$, and $\mathrm{Cd}$ ), alkalinity, hardness, and sulfate concentration. Alkalinity and hardness were measured by titration (American Public Health Association 2005). Sulfate concentrations were determined by colorimetric detection using a Hach 2100 spectrophotometer (Hach Inc., Loveland, Colorado, USA). A subsample of each surface-water sample was filtered on-site into a precleaned polyethylene bottle using a polypropylene syringe and filter cartridge $(0.45 \mu \mathrm{m}$ pore size), placed on ice, refrigerated, and subsequently acidified to $1 \%(\mathrm{v} / \mathrm{v})$ with nitric acid within 4 days of collection. Water samples were analyzed for $\mathrm{Pb}$, $\mathrm{Zn}$, and $\mathrm{Cd}$ using semiquantitative multielement inductively-coupled plasma-mass spectrometry (ICP-MS).

Crayfish were subsampled from those collected during kick-seine sampling for metals analyses. Generally, five crayfish from each riffle at each site were composited for analysis; however, samples from three sites (T4, S1, and S4) contained only three crayfish per riffle. Crayfish were rinsed with site water and placed in precleaned high-density polyethylene (HDPE) containers. Detritus (e.g., weathered leaves) was collected with a kick net and by hand on the day of crayfish sampling at the stream banks of each riffle sampled and placed in precleaned $125 \mathrm{~mL}$ HDPE bottles. Samples of crayfish and detritus were placed on ice, frozen $\left(-20^{\circ} \mathrm{C}\right)$ within $6 \mathrm{~h}$ of collection, and stored frozen until analyzed. Animal tissues and organic material were lyophilized (i.e., freeze-dried) and decreased to a coarse powder by mechanical crushing in a glass vial with a glass rod. Neither exoskeletons nor gut contents of the crayfish were removed before analyses. A dry mass of $0.25 \mathrm{~g}$ from each composite sample of crayfish or detritus sample was digested using concentrated nitric acid and microwave heating before being analyzed for $\mathrm{Pb}, \mathrm{Zn}$, and Cd using ICP-MS (Allert et al. 2008, 2009a; Besser et al. 2007). Surficial sediments (approximately the top $10 \mathrm{~cm}$ ) were collected within the wetted stream channel of each riffle at each site using PVC scoops rinsed with site water before collection (Besser et al. 2009b). Sediment samples were composited and wet-sieved through a $2 \mathrm{~mm}$ stainlesssteel mesh sieve in the field to remove coarse particles using a minimal quantity of site water (Besser et al. 2009b; Brumbaugh et al. 2007); placed in precleaned $125 \mathrm{~mL}$ glass bottles on ice; then refrigerated $\left(-4{ }^{\circ} \mathrm{C}\right)$ until analyzed. In the laboratory, a subsample of the $<2 \mathrm{~mm}$ sediment sample was sieved using a $250 \mu \mathrm{m}$ stainless-steel 
mesh sieve. Total recoverable (TR) metals $(\mathrm{Pb}, \mathrm{Zn}$, and $\mathrm{Cd})$ in the $<2$ and $<250 \mu \mathrm{m}$ sediment fraction were analyzed by ICP-MS (Brumbaugh et al. 2007; May et al. 1997).

Site-mean TR metals concentrations in the $<250 \mu \mathrm{m}$ sediment fraction were converted to probable-effects quotients (PEQs) by dividing site-mean TR metals concentrations by TSMD-specific probable-effects concentrations (PECs; MacDonald et al. 2000, 2010) for each metal. Individual PEQs for the three metals were summed ( $\sum$ PEQs) to estimate risks from the metal mixtures (Besser et al. 2009a; Ingersoll et al. 2001). In general, $\sum$ PEQs greater than one are assumed to indicate a greater hazard of toxic effects (Besser et al. 2009a); however, MacDonald et al. (2010) calculated low-risk ( $\left.\sum P E Q=6.47\right)$ and highrisk $\left(\sum \mathrm{PEQ}=10.04\right)$ toxicity thresholds for $\mathrm{Pb}, \mathrm{Zn}$, and $\mathrm{Cd}$ in TSMD sediments to better assess risks of toxicity in the TSMD.

The cumulative risk of toxic effects from metals in surface water was estimated using a toxic units (TU) approach (Wildhaber and Schmitt 1996). A TU is defined as the measured concentration of each dissolved metal in surface water divided by the chronic ambient water-quality criterion for the metal adjusted for hardness and the dissolved fraction of metal (USEPA 2005, 2006). TUs for metals were summed to produce a total toxicity estimate of the mixture (i.e., $\mathrm{TU}$ unit score $=\sum \mathrm{TU}$ ) for site means; values $>1.0$ generally indicate potential toxicity to aquatic biota.

Increased concentrations of metals in fish and crayfish within the TSMD represent a risk to fish and carnivorous wildlife (Schmitt et al. 2006, 2008). The screening-level criteria developed by Schmitt et al. (2006) were used to assess the potential hazards of metals in crayfish collected during this study to carnivorous wildlife. Toxicity thresholds of metals in target species were determined through food-chain analysis using procedures developed for conducting ecological-risk assessments (USEPA 1992, 1993, 1997, 1999, 2007). This assessment used representative bird and mammal species based on body weight, such as the American robin (Turdus migratorius) and short-tailed shrew (Blarina brevicauda), which can be extrapolated to similar-sized species that consume crayfish. Hazard quotients (HQs) were calculated using site mean concentrations of $\mathrm{Pb}, \mathrm{Zn}$, and $\mathrm{Cd}$ in crayfish and no-effect hazard concentrations (NEHCs) to estimate daily contaminant intake rates; NEHCs are consensus-based no-adverse effect level-based toxic reference values normalized for estimated daily food ingestion rates (Schmitt et al. 2008). All assume a diet of $100 \%$ crayfish. There is no analogous procedure to assess risk to predatory fish.

All statistical analyses were conducted using Statistical Analysis System (release 9.1; SAS, Chicago, IL) for
Windows. Before analyses, data were tested for normality and homogeneity of variance using Shapiro-Wilk statistic. Data were not normally distributed; therefore, all analyses were conducted using rank-transformed data (Conover and Iman 1981). Ranks of site means for crayfish density, water-quality variables, physical habitat quality variables, and metal concentrations were used in the statistical analyses. Censored values [less than method detection limit (MDL); Supplemental Table S1] were replaced with $50 \%$ of the MDL for statistical computations, figures, and tables; only metal concentrations in surface water samples from reference sites were censored.

Differences among groups of sites (i.e., reference, mining, downstream) were tested using nested analysis of variance (ANOVA; riffles within sites) with site considered a fixed effect. Differences in measured variables were tested as planned nonorthogonal contrasts using single $d f$ $F$-tests. The within-site mean squares for ranked variables were used in all tests, which were conducted using PROC GLM. Associations between site means metal concentrations were examined using Spearman's rank correlation analyses (Supplemental Table S2) and indicated a high degree of correlation between metals. Separate linear regression of $O$. n. neglectus and $O$. macrus densities against physical and chemical habitat variables was performed using PROC REG with variable selection based on Akaike's information criterion (AIC; Burnham and Anderson 2002). In these analyses, models were evaluated relative to each other based on corrected AIC values (AICc). The AICc values are adjusted upward for sample size relative to the number of independent variables, which protects against over-fitting models due to small sample size (Burnham and Anderson 2002). The best-fit equally fit model (variables $n=30$ ) for $O$. $n$. neglectus density included five variables: current velocity; $\mathrm{Pb}$ and $\mathrm{Cd}$ in detritus; temperature and $\mathrm{pH} ; R^{2}=0.89$; and $\mathrm{AICc}=$ 55.65. The best two equally fit models for $O$. macrus density included two variables: alkalinity and current velocity $\left(R^{2}=0.99\right.$; $\left.\mathrm{AICc}=-6.68\right)$ or $\mathrm{Pb}$ in surface water and $\mathrm{Zn}$ in crayfish $\left(R^{2}=0.99\right.$; AICc $\left.=-5.99\right)$. The relationship among $O$. n. neglectus and $O$. macrus densities and the variables identified in the best-fit models were further examined with principal component analyses (PCA). A significance level of $P<0.05$ was used to judge all statistical tests. Supplemental material contains site mean summaries.

\section{Results}

Crayfish were collected at all sites (Supplemental Table S3). Only one crayfish species, Orconectes (Procericambarus) neglectus neglectus Faxon (ringed crayfish), was 
Table 2 Mean densities of $O$. n. neglectus, water depth, and $\sum \mathrm{PEQ}$ and $\sum \mathrm{TU}$ for $\mathrm{Pb}, \mathrm{Zn}$, and $\mathrm{Cd}$

\begin{tabular}{lllll}
\hline Site group & $O$. n. neglectus density $\left(\mathrm{n} / \mathrm{m}^{2}\right)$ & $\sum$ PEQ & $\sum$ TU & Water depth $(\mathrm{cm})$ \\
\hline Reference $^{\mathrm{a}}$ & $16.9(4.0)$ & $9.2(2.1)$ & $0.23(0.07)$ & $21.8(2.7)$ \\
Mining $^{\mathrm{b}}$ & $4.79(1.33)$ & $38.7(6.3)$ & $1.14(0.14)$ & $26.4(2.4)$ \\
Downstream $^{\mathrm{c}}$ & $1.68(0.41)$ & $22.3(4.0)$ & $0.57(0.15)$ & $24.8(1.9)$ \\
R versus M & $F_{(15,32)}=15.0^{* *}$ & $F_{(15,32)}=352^{* *}$ & $F_{(15,32)}=2,191^{* *}$ & $F_{(15,32)}=6.41^{* *}$ \\
R versus D & $F_{(15,32)}=33.6^{* *}$ & $F_{(15,32)}=111^{* *}$ & $F_{(15,32)}=484^{* *}$ & $F_{(15,32)}=4.88^{*}$ \\
D versus M & $F_{(15,32)}=5.44^{*}$ & $F_{(15,32)}=39.3 * *$ & $F_{(15,32)}=395^{* *}$ & $F_{(15,32)}=0.00 \mathrm{~ns}$ \\
\hline
\end{tabular}

Data shown are arithmetic site groups means \pm SEs. Also shown are results of one-way ANOVA as $F$ values and $d f$ for differences among site groups $(* * p \leq 0.01 ; * 0.01 \leq p \leq 0.05$; ns $\geq 0.05$ ). Within-site mean squares for ranked variables were used in all tests

$R$ reference site, $M$ mining site, $D$ downstream site

${ }^{a}$ Reference sites: J1, C1, T1, T2, S1, and S2

${ }^{b}$ Mining sites: C2, C3, C4, T3, S3, and S6

${ }^{c}$ Downstream sites: T4, C5, S4, and S5

collected at all sites. There were significant differences in mean densities of $O$. n. neglectus among site types; mean densities were significantly lower at mining and downstream sites than reference sites (Table 2). Orconectes (Procericambarus) macrus Williams (Neosho midget crayfish) was only collected at reference sites (J1, C1, S1, and S2). Mean densities of O. macrus were threefold greater than $O . n$. neglectus densities at $\mathrm{C} 1$; however, at the three other sites where both species were collected (J1, S1, and S2), mean densities of $O$. n. neglectus were 1.5- to 5-fold greater than O. macrus (Supplemental Table S3). A third species, Orconectes (Gremicambarus) virilis Hagen (virile crayfish), was collected only at $\mathrm{J} 1(n=3)$ and $\mathrm{C} 1$ $(n=2)$.

Preliminary analyses showed there were no significant differences in mean CL between sexes for either $O$. $n$. neglectus $\left(F_{(1,226)}=2.29 ; \quad P=0.13\right)$ or $O$. macrus $\left(F_{(1,54)}=3.37 ; P=0.06\right)$. However, there were significant differences in mean CL among sites $\left(F_{(1,226)}=2.29\right.$; $P=0.13$ ) and site groups for $O$. n. neglectus collected for metal analyses: Crayfish from reference sites were significantly larger than crayfish collected at mining or downstream sites (reference vs. mining $F_{(3,15)}=159$; $P<0.001$; reference vs. downstream $F_{(3,15)}=123$; $P<0.001$; and mining vs. downstream $F_{(3,15)}=0$; $P=0.954)$. $O$. macrus were only collected at reference sites; however, there were no significant differences in CLs of $O$. macrus collected for metals analyses among sites $\left(F_{(3,52)}=0.46 ; P=0.714\right)$.

Mean concentrations of $\mathrm{Pb}, \mathrm{Zn}$, and $\mathrm{Cd}$ in $O$. n. neglectus, surface water, $<250 \mu \mathrm{m}$ sediment fraction, and detritus were significantly correlated (Supplemental Table S2) and significantly greater at mining and downstream sites than at reference sites (Table 3; Supplemental Tables $\mathrm{S} 4$ through $\mathrm{S} 7$ ). Concentrations of metals in $O$. macrus were significantly greater than those in $O$. n. neglectus in
11 of the 12 comparisons (Supplemental Table S4). Mean concentrations of $\mathrm{Pb}, \mathrm{Zn}$, and $\mathrm{Cd}$ in the $<250 \mu \mathrm{m}$ sediment fraction approached or exceeded TSMD-specific high-risk concentrations $\left(\mathrm{PEC}_{20}\right.$; concentrations associated with a $20 \%$ decrease in a measured end point at all site groups (Table 3; Supplemental Table S6; MacDonald et al. 2010). Mean concentrations of $\mathrm{Pb}$ in surface water did not exceed the chronic USEPA water-quality criterion at any site group; however, mean concentration of $\mathrm{Zn}$ and $\mathrm{Cd}$ did exceed these criteria at mining sites (Table 3 ).

Sediment $\sum$ PEQs indicated risk of toxicity at mining and downstream sites (Table 2; Supplemental Table S8); $\sum$ PEQs were greater than both the TSMD-specific low$\left(\sum \mathrm{PEQs}=6.47\right)$ and high-risk $\left(\sum \mathrm{PEQs}=10.04\right)$ toxicity thresholds at mining and downstream sites (MacDonald et al. 2010). O. n. neglectus densities were decreased relative to reference sites where TSMD-specific $\sum$ PEQs were exceeded (Fig. 2). Surface water $\sum$ TUs were significantly greater at mining and downstream sites than at reference sites (Table 2; Supplemental Table S9). Surface water $\sum$ TUs at all mining sites were $<1$, indicating potential risk to aquatic biota.

Criteria used to evaluate risks of $\mathrm{Pb}, \mathrm{Zn}$, and $\mathrm{Cd}$ concentrations in crayfish to wildlife indicated that metals concentrations at mining and downstream sites are potentially hazardous to carnivorous wildlife (Fig. 3). HQs were greater for birds than mammals in their respective size category (Supplemental Tables S10 and S11). HQs for mean concentrations of $\mathrm{Pb}$ and $\mathrm{Zn}$ in $O$. n. neglectus were $>1.0$ for robin-size birds at mining and downstream sites. The Cd hazard quotient was $<1.0$ for robin-sized birds and approached 1.0 for shrew-size mammals at mining sites (Fig. 3).

Mean water depth and current velocities were significantly greater at mining and downstream sites than at reference sites (Table 2; Supplemental Tables S12 and S13). 
Table 3 Metal concentrations in $O . n$. neglectus, detritus, $<250 \mu \mathrm{m}$ fraction of sediment, and surface water
Data shown are arithmetic site groups means \pm SEs. Also shown are results of one-way ANOVA as $F$ values and $d f$ for differences among site group $(* * p \leq 0.001 ; \mathrm{ns} \geq 0.05)$.

Within-site mean squares for ranked variables were used in all tests

$R$ reference site, $M$ mining site, $D$ downstream site

$* 0.01 \leq p \leq 0.05$

${ }^{a}$ Reference sites: J1, C1, T1, $\mathrm{T} 2$, S1, and $\mathrm{S} 2$

b Mining sites: C2, C3, C4, T3, $\mathrm{S} 3$, and $\mathrm{S} 6$

c Downstream sites: T4, C5, S4, and S5

${ }^{\mathrm{d}} \mathrm{PEC}_{20}=$ TSMD probableeffects concentration high-risk threshold associated with a $20 \%$ decrease in a measured end point (MacDonald et al. 2010)

${ }^{\mathrm{e}} \mathrm{WQC}=$ federal water-quality criteria adjusted for hardness and the dissolved fraction of the metal (USEPA 2006)

\begin{tabular}{|c|c|c|c|}
\hline Site group/criteria & $\mathrm{Pb}$ & $\mathrm{Zn}$ & $\mathrm{Cd}$ \\
\hline & \multicolumn{3}{|c|}{ O. n. neglectus ( $\mu \mathrm{g} / \mathrm{g}$ dry weight) } \\
\hline Reference $^{\mathrm{a}}$ & $3.65(0.7)$ & $159(17)$ & $1.22(0.24)$ \\
\hline Mining $^{\mathrm{b}}$ & $10.1(1.7)$ & $339(26)$ & $5.76(0.77)$ \\
\hline Downstream $^{c}$ & $10.5(2.6)$ & $272(35)$ & $3.81(0.94)$ \\
\hline$R$ versus $M$ & $F_{(15,32)}=47.3^{* *}$ & $F_{(15,32)}=120 * *$ & $F_{(15,32)}=531 * *$ \\
\hline$R$ versus $D$ & $F_{(15,32)}=22.3^{* *}$ & $F_{(15,32)}=32.4^{* *}$ & $F_{(15,32)}=155^{* *}$ \\
\hline$D$ versus $M$ & \multicolumn{2}{|c|}{ Detritus ( $\mu \mathrm{g} / \mathrm{g}$ dry weight) } & $F_{(15,32)}=66.6^{*}$ \\
\hline $\mathrm{R}$ & $156(36)$ & $3,281(663)$ & $34(11)$ \\
\hline M & $643(70)$ & $10,772(1,438)$ & $138(20)$ \\
\hline $\mathrm{D}$ & $543(124)$ & $8,500(1,261)$ & $92(20)$ \\
\hline$R$ versus $M$ & $F_{(15,32)}=167 * *$ & $F_{(15,32)}=312 * *$ & $F_{(15,32)}=129 * *$ \\
\hline$R$ versus $D$ & $F_{(15,32)}=71.9 * *$ & $F_{(15,32)}=132 * *$ & $F_{(15,32)}=41.6^{* *}$ \\
\hline \multirow[t]{2}{*}{$D$ versus $M$} & $F_{(15,32)}=9.59 * *$ & $F_{(15,32)}=18.8^{* *}$ & $F_{(15,32)}=13.6^{* *}$ \\
\hline & \multicolumn{3}{|c|}{$<250 \mu \mathrm{m}$ sediment fraction ( $\mu \mathrm{g} / \mathrm{g}$ dry weight) } \\
\hline $\mathrm{R}$ & $235(73)$ & $2,093(409)$ & $14.0(3.7)$ \\
\hline M & $947(231)$ & $8,991(1,435)$ & $58.6(8.7)$ \\
\hline $\mathrm{D}$ & $534(128)$ & $5,393(1,011)$ & $31.9(4.2)$ \\
\hline$R$ versus $M$ & $F_{(15,32)}=155^{* *}$ & $F_{(15,32)}=235^{* *}$ & $F_{(15,32)}=341 * *$ \\
\hline$R$ versus $D$ & $F_{(15,32)}=51.2 * *$ & $F_{(15,32)}=54.5^{* *}$ & $F_{(15,32)}=93.4 * *$ \\
\hline$D$ versus $M$ & $F_{(15,32)}=15.9^{* *}$ & $F_{(15,32)}=40.1 * *$ & $F_{(15,32)}=47.1^{* *}$ \\
\hline \multirow[t]{2}{*}{$\mathrm{PEC}_{20}{ }^{\mathrm{d}}$} & 179 & 2,409 & 14.1 \\
\hline & \multicolumn{3}{|c|}{ Surface water $(\mu \mathrm{g} / \mathrm{L})$} \\
\hline $\mathrm{R}$ & $0.17(0.04)$ & $43.2(13.4)$ & $0.14(0.17)$ \\
\hline M & $0.56(0.13)$ & $235(33)$ & $0.91(0.16)$ \\
\hline $\mathrm{D}$ & $0.40(0.09)$ & $93.9(25.1)$ & $0.43(0.16)$ \\
\hline$R$ versus $M$ & $F_{(15,32)}=17.4^{* *}$ & $F_{(15,32)}=8.68^{* *}$ & $F_{(15,32)}=7.41 * *$ \\
\hline$R$ versus $D$ & $F_{(15,32)}=180 * *$ & $F_{(15,32)}=373 * *$ & $F_{(15,32)}=439 * *$ \\
\hline$D$ versus $M$ & $F_{(15,32)}=93.7 * *$ & $F_{(15,32)}=482 * *$ & $F_{(15,32)}=343^{* *}$ \\
\hline $\mathrm{WQC}^{\mathrm{e}}$ & $5-9$ & $93-145$ & $0.4-0.6$ \\
\hline
\end{tabular}

Substrate coarseness was not significantly difference among site groups (Supplemental Tables S12 and S13). In situ water-quality variables generally did not exceed state or federal criteria (Supplemental Tables S14 and S15). However, water-quality constituents associated with metalmining, such as specific conductance and concentrations of hardness and sulfate, were significantly greater at mining than at reference sites (Supplemental Tables S16 and S17).

A series of interpretable ordinations were obtained by PCA for each species (Fig. 4). Each ordination resulted in the first two PCA axes explaining more of the variation (69-90\%) than expected by chance alone. In the ordination for the $O$. n. neglectus, variables with strong positive associations with PC1 included $\mathrm{Pb}(0.67)$ and $\mathrm{Cd}(0.64)$ in detritus. Current velocity (0.58) had a strong positive association, but density $(-0.65)$ had a strong negative association with PC2. Reference sites were separated from all other sites with negative values for PC1, whereas mining sites had positive values. In the ordination for O. macrus, density $(-0.45)$ had a strong negative association with $\mathrm{PC} 1$, whereas, temperature (0.47) and alkalinity (0.41) had a strong positive association with PC1. Variables that had strong positive associations with PC2 included $\mathrm{Pb}$ in surface water (0.66) and $\mathrm{Zn}$ in the $<250 \mu \mathrm{m}$ fraction of sediment (0.47). Current velocity had a strong negative association $(-0.46)$. These ordinations suggest that habitat variables and metals are important in explaining densities of $O$. n. neglectus and O. macrus among sites.

\section{Discussion}

Our results indicate that environmental metals concentrations remain increased in the TSMD as indicated by high metal concentrations in surface water, sediment, detritus, and crayfish in the streams investigated. We found 


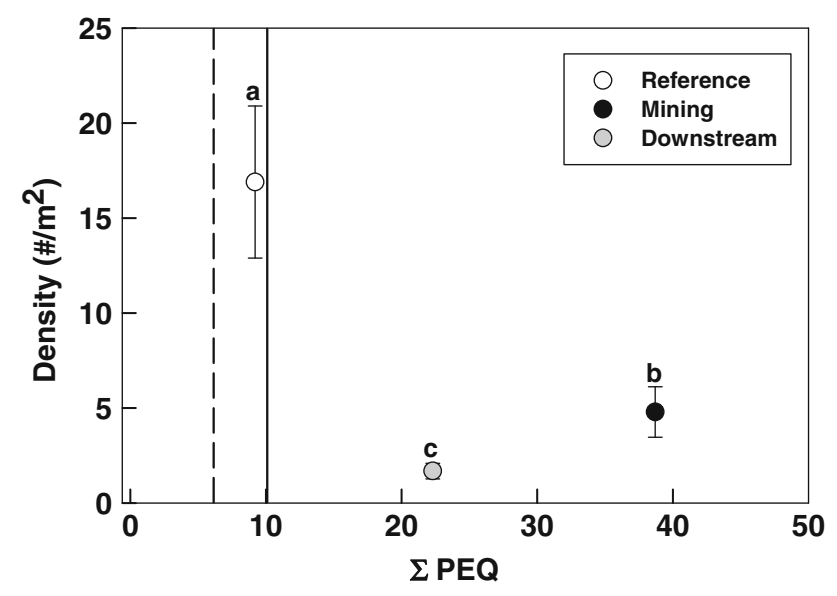

Fig. 2 Relationship between sediment $\sum$ PEQs (MacDonald et al. 2010) and mean densities of $O$. n. neglectus. Lines represent TSMD low-risk (dashed line) and high-risk (solid line) toxicity thresholds (MacDonald et al. 2010)

decreased densities of $O . n$. neglectus and the absence of $O$. macrus at mining-affected sites as well as a negative association of crayfish densities with metal concentrations. Our results are consistent with previous investigations that have documented increased metal concentrations in macroinvertebrates, fish, detritus, and sediment in the TSMD (Angelo et al. 2007; Brumbaugh et al. 2005; MacDonald et al. 2010; Schmitt et al. 1993, 2006; Wildhaber et al. 1997, 2000) and that documented the absence or decreased densities of crayfish below mining-affected sites in the Viburnum Trend Mining District of southeast Missouri (Allert et al. 2008, 2009a). Allert et al. (2009a) also documented decreased survival of caged crayfish at sites directly downstream $(0.4-3.7 \mathrm{~km})$ of mining sites. Survival and biomass of caged crayfish were significantly lower at mining sites than reference or downstream sites, and survival was negatively correlated with metal concentrations in surface water, detritus, macroinvertebrates, stonerollers, and whole crayfish. In situ testing of crayfish was an important tool for showing that the absence of crayfish populations below mining sites was the result of metal exposure as opposed to habitat loss due to physical impairment by mine waste (e.g., sedimentation by mine tailings).

Although the diversity of crayfish in the Missouri Ozarks is high ( $>25$ species; Pfleiger 1996), many taxa are restricted to a single drainage and are further restricted within drainages due to macrohabitat partitioning between species (DiStefano et al. 2003; Flinders and Magoulick 2005; Rabeni 1985). O. macrus is endemic to the Ozark Highlands and is primarily found in the westward-flowing rivers north of the Illinois River in Oklahoma, including the Spring River. Within the Spring River drainage, $O$. macrus does not occur in the North Fork Spring River or in

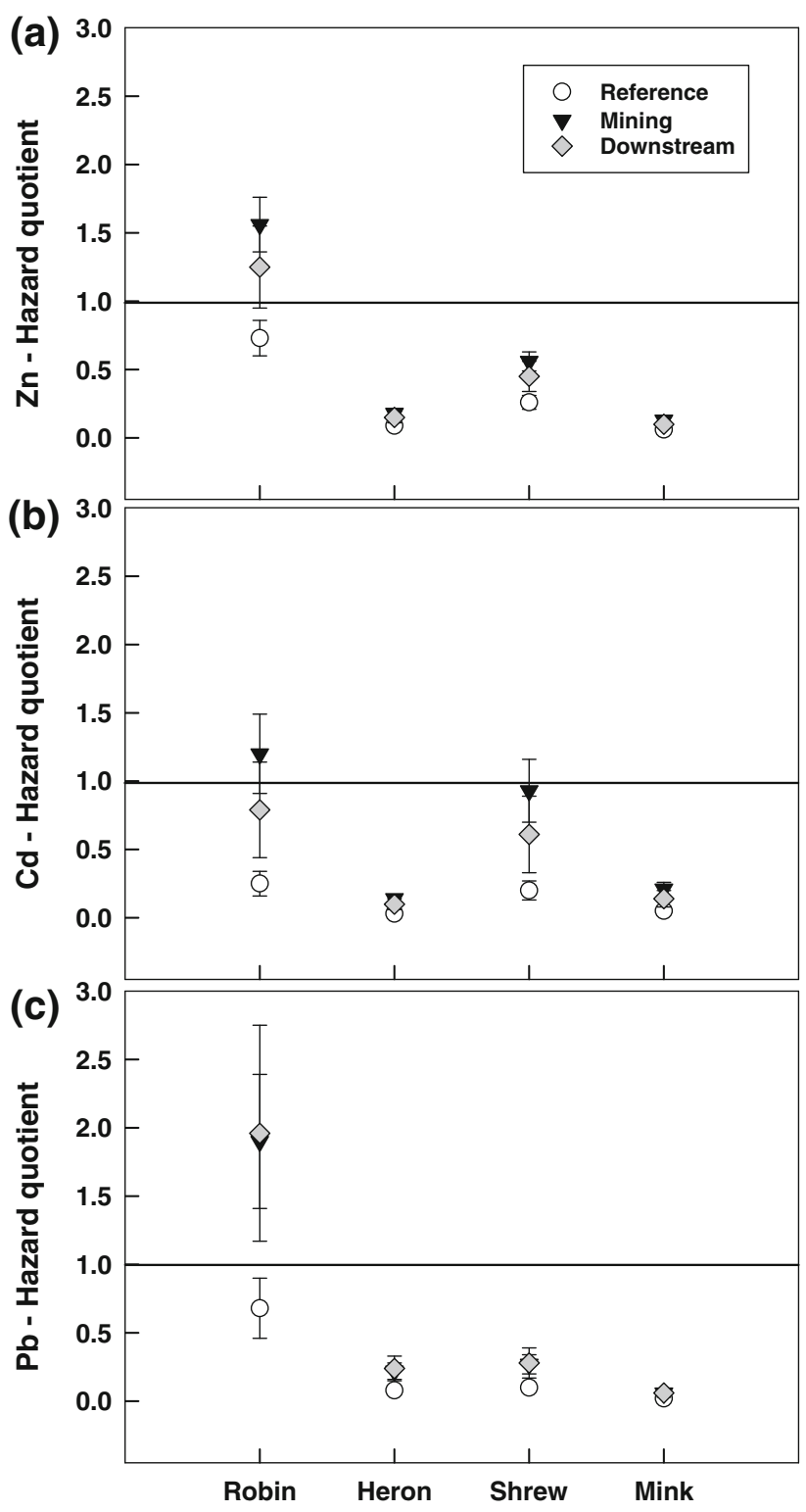

Fig. $3 \mathrm{HQs}$ for dietary metal exposure for representative species for a $\mathrm{Zn}, \mathbf{b} \mathrm{Cd}$, and $\mathbf{c} \mathrm{Pb}$ in $O$. n. neglectus. Line represents risk threshold

portions of Shoal Creek (Dillman et al. 2010; Pfleiger 1996). O. macrus typically inhabits rocky substrates in swift, shallow water and is a relatively sedentary species that spends most of its time in cavities beneath rocks or in excavated tunnels in gravelly substrate (Pfleiger 1996). It is unclear why $O$. macrus is not found at sites in the lower reaches of Center Creek and Shoal Creek despite being present in the lower Neosho River and Spring River (Dillman et al. 2010). O. macrus may be more sensitive to metals than $O . n$. neglectus, or its sedentary nature within excavated tunnels may expose $O$. macrus to greater metal concentrations typical of porewater and sediment (Brumbaugh et al. 2007). Either or both mechanisms could have eliminated $O$. macrus from Center Creek and Shoal 

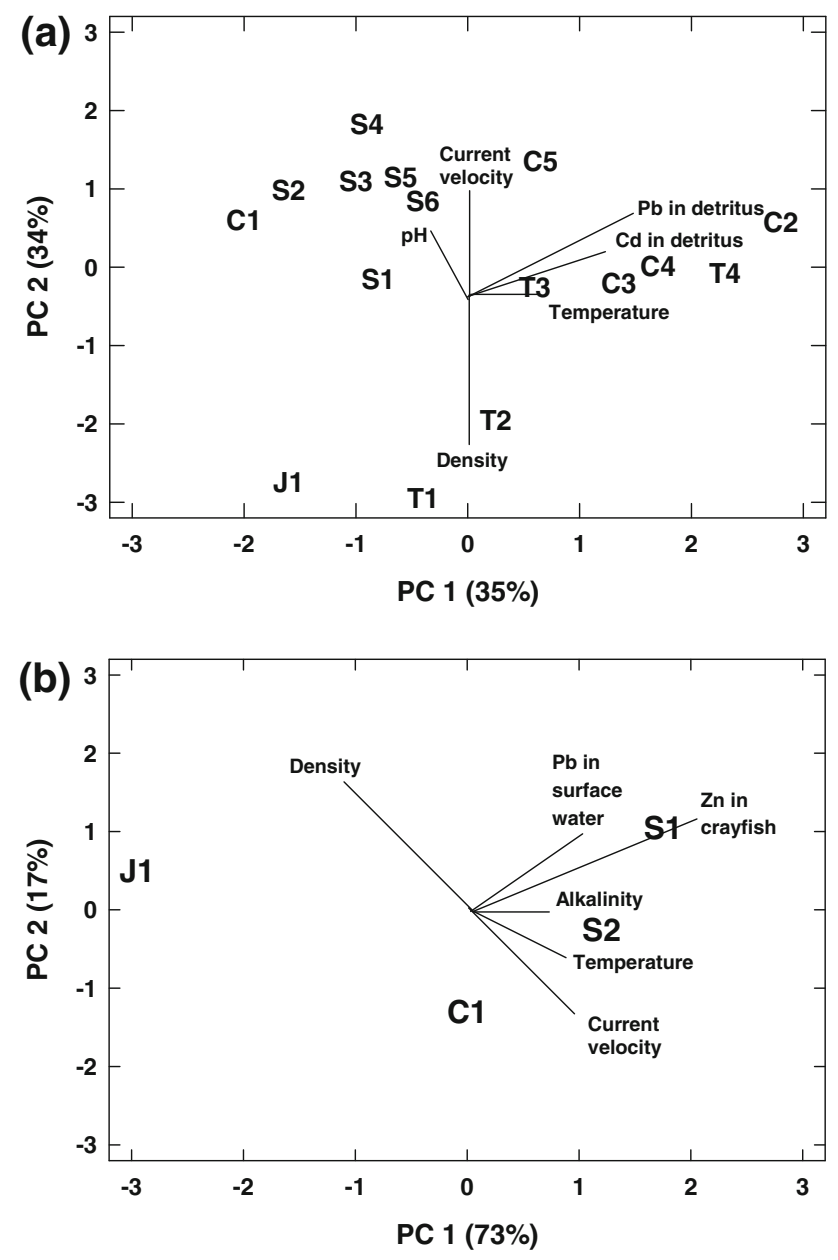

Fig. 4 PC ordination for selected physical habitat and water-quality variables and a mean densities of $O$. n. neglectus and $\mathbf{b}$ mean densities of $O$. macrus. Variables strongly associated with the axes are shown: the lengths of the lines leading from the centroid toward the labels are proportional to the strength of the correlation of that variable with the axes

Creek where metals concentrations are high (Allert et al. 1997, 2008, 2009a; Knowlton et al. 1983; Wigginton and Birge 2007).

Previous studies differed in their characterization of habitat selection by $O$. neglectus. Gore and Bryant (1990) found that $O$. neglectus partition their habitats, with young typically found in moderate-velocity $(25-45 \mathrm{~cm} / \mathrm{s})$ cobble habitats and adults in low-velocity $(0 \mathrm{~cm} / \mathrm{s})$ macrophyte beds or high-velocity $(>65 \mathrm{~cm} / \mathrm{s})$ cobbled habitats. However, other studies (Flinders and Magoulick 2005; Magoulick and DiStefano 2007) reported no significant difference in habitat selection by different size classes of $O$. neglectus or O. $n$. chaenodactylus (Williams 1952). The range of water depth, current velocities, and substrate in riffles measured in our study were comparable with previously reported values (Flinders and Magoulick 2005; Magoulick and DiStefano 2007; Rabalais and Magoulick
2006). Current velocities in riffles at sites in Center Creek and Shoal Creek $(>0.60 \mathrm{~cm} / \mathrm{s})$ were greater than previously reported ranges for young $O$. neglectus (Gore and Bryant 1990), which may have limited densities in riffles of those creeks. Several studies (Flinders and Magoulick 2005; Rabalais and Magoulick 2006) have reported that $O$. $n$. chaenodactylus densities were negatively correlated with water depth in larger streams (stream order $>3$ ), possibly explaining the lower densities of $O . n$. neglectus in Shoal Creek, which was significantly deeper than the other streams sampled in our study. The inverse relation between crayfish density and stream size ( $\geq 5$ orders) or watershed size may be related to the proportional decrease in allochthonous materials in larger streams (Vannote et al. 1980), loss of habitat heterogeneity (Clark 2009; Mitchell and Smock 1991), smaller percentage of suitable habitat (Burkey and Simon 2010; DiStefano et al. 2008; Lodge and Hill 1994; Westhoff et al. 2006), or increased predation (Flinders and Magoulick 2003; Hill and Lodge 1995; Stein and Magnuson 1976).

Previous studies have used crayfish to assess the bioavailability of metals through the analysis of whole-body crayfish (Allert et al. 2008, 2009a, 2010; Besser et al. 2007; Schmitt et al. 2006, 2008). Crayfish, freshwater mussels, and benthic fishes have been identified as possible sentinel organisms in the investigation of heavy-metal pollution in the environment because of their important functional role in streams and limited home ranges (Allert et al. 2008, 2009a, 2009b, 2010; Angelo et al. 2007; Maret and MacCoy 2002). Dietary pathways have been identified as important routes of metal exposure (Besser et al. 2005; Farag et al. 1999). Therefore, the likelihood of food-chain transfer of metals from crayfish and other environmental media to wildlife in the TSMD is high and potentially hazardous.

\section{Conclusion}

Crayfish densities were significantly decreased downstream of mine waste relative to upstream reference sites. Decreased crayfish densities imply a loss of ecosystem function because crayfish are a key structural and functional component of Ozark streams and their surrounding ecosystems. This study provides additional support for the use of crayfish in the assessment of the bioavailability and ecological effects of metals in aquatic ecosystems. However, risk assessments are more effective when contaminant (e.g., metals) concentrations are linked with the status of aquatic organisms (e.g., crayfish density) and toxicological information (e.g., mortality or other sublethal measurements). In situ and laboratory toxicity tests would provide additional information regarding metal exposure, 
the bioaccumulation of metals, and the potential toxicity to known age classes of crayfish because it is impossible to observe temporal changes and bioaccumulation in the environment. Genomic research may provide information on the association of distribution and metal concentrations among crayfish in the TSMD.

Acknowledgments We thank the private landowners who allowed us to access the studied streams. Personnel who assisted in the study included staff from the Missouri Department of Conservation and from the United States Geological Survey (USGS) Columbia Environmental Research Center. We thank J. Besser, J. Hinck, N. Wang, and two anonymous reviewers for providing insightful comments that greatly improved the quality of this manuscript. This study was jointly funded by the USGS, the United States Department of the Interior Natural Resource Damage Assessment and Restoration Program, the Missouri Department of Conservation, and the Missouri Department of Natural Resources. This manuscript has been reviewed in accordance with USGS policy. All procedures performed conformed with USGS guidelines for the humane treatment of the test organisms during culture and experimentation. The use of trade names does not constitute USGS or United States Government endorsement.

\section{References}

Allert AL, Wildhaber ML, Schmitt CJ, Chapman D, Callahan E (1997) Toxicity of sediments and pore-waters and their potential impact on Neosho madtom, Noturus placidus, in the Spring River system affected by historic zinc-lead mining and related activities in Jasper and Newton Counties, Missouri; and Cherokee County, Kansas. Final report to the United States Fish and Wildlife Service-Region 3, Columbia Missouri Ecological Services Field Office. United States Geological Survey, Columbia Environmental Research Center, Columbia

Allert AL, Fairchild JF, DiStefano RJ, Schmitt CJ, Besser JM, Brumbaugh WG et al (2008) Effects of lead-zinc mining on crayfish (Orconectes hylas) in the Black River watershed, Missouri. Freshw Crayfish 16:97-111

Allert AL, Fairchild JF, DiStefano RJ, Schmitt CJ, Brumbaugh WG, Besser JM (2009a) Ecological effects of lead mining on Ozark streams-in-situ toxicity to woodland crayfish (Orconectes hylas). Ecotoxicol Environ Saf 72:1207-1219

Allert AL, Fairchild JF, Schmitt CJ, Besser JM, Brumbaugh WG, Olson SJ (2009b) Effects of mining-derived metals on riffledwelling benthic fishes in Southeast Missouri, USA. Ecotoxicol Environ Saf 72(6): 1642-1651

Allert AL, DiStefano RJ, Fairchild JF, Schmitt CJ, Brumbaugh WG (2010) Effects of mining-derived metals on riffle-dwelling crayfish and in-situ toxicity to juvenile Orconectes hylas and Orconectes luteus in the Big River of southeast Missouri, USA. United States Geological Survey Administrative report, submitted to the United States Fish and Wildlife Service, Columbia

American Public Health Association, American Water Works Association, and Water Environment Federation (2005) Standard methods for the examination of water and wastewater. American Public Health Association, Washington DC

Angelo RT, Cringan MS, Chamberlain DL, Stahl AJ, Haslouer SG, Goodrich CA (2007) Residual effects of lead and zinc mining on freshwater mussels in the Spring River Basin (Kansas, Missouri, and Oklahoma, USA). Sci Total Environ 384:467-496

Bain MB, Stevenson NJ (1999) Aquatic habitat assessment-common methods. American Fisheries Society, Bethesda
Bain MA, Finn JT, Booke HE (1985) Quantifying stream substrate for habitat analysis studies. N Am J Fish Manag 5:499-506

Barks JH (1977) Effects of abandoned lead and zinc mines and tailings piles on water quality in the Joplin area, Missouri. United States Geological Survey Water Resources Investigations Report 77-75. United States Geological Survey, Rolla

Besser JM, Brumbaugh WG, Brunson EL, Ingersoll CG (2005) Acute and chronic toxicity of lead in water and diet to the amphipod Hyalella azteca. Environ Toxicol Chem 24(7):1807-1815

Besser JM, Brumbaugh WG, May TW, Schmitt CJ (2007) Biomonitoring of lead, zinc, and cadmium in streams draining leadmining and non-mining areas, southeast Missouri, USA. Environ Monit Assess 129:227-241

Besser JM, Brumbaugh WG, Allert AL, Poulton BC, Schmitt CJ, Ingersoll CG (2009a) Ecological impacts of lead mining on Ozark streams-toxicity of sediment and pore water. Ecotoxicol Environ Saf 72:516-526

Besser JM, Brumbaugh WG, Hardesty DK, Hughes JP, Ingersoll CG (2009b) Assessment of metal-contaminated sediments from the Southeast Missouri (SEMO) mining district using sediment toxicity tests with amphipods and freshwater mussels. United States Geological Survey Administrative report submitted to the United States Fish and Wildlife Service, Ecological Services Office, Region 3, Environmental Contaminants Division, Columbia Missouri. United States Geological Survey, Columbia

Brumbaugh WG, Schmitt CJ, May TW (2005) Concentrations of cadmium, lead, and zinc in fish from mining-influenced waters of northeastern Oklahoma-sampling of blood, carcass, and liver for aquatic biomonitoring. Arch Environ Contam Toxicol 49:76-88

Brumbaugh WG, May TW, Besser JM, Allert AL, Schmitt CJ (2007) Assessment of elemental concentrations in streams of the New Lead Belt in southeastern Missouri, 2002-05. United States Geological Survey Scientific Investigations Report 2007-5057. http://pubs.usgs.gov/sir/2007/5057/. Accessed 14 May 2009

Burkey JL, Simon TP (2010) Reach- and watershed-scale associations of crayfish within an area of varying agricultural impact in WestCentral Indiana. Southeast Nat 9(sp3):199-216

Burnham KP, Anderson DR (2002) Model selection and multimodel inference: a practical information theoretic approach, 2nd edn. Springer-Verlag, New York, p 488

Clark JM (2009) Abiotic and biotic factors affecting size-dependent crayfish (Orconectes obscures) distribution, density, and survival. Doctoral dissertation, Kent State University, Kent

Conover WJ, Iman RL (1981) Rank transformations as a bridge between parametric and nonparametric statistics. Am Stat 35:124-129

Creed RP Jr (1994) Direct and indirect effects of crayfish grazing in a stream community. Ecology 75:2091-2103

Czarnezki JM (1985) Accumulation of lead in fish from Missouri streams impacted by lead mining. Bull Environ Contam Toxicol 34:736-745

Davis JV, Schumacher JG (1992) Water quality characterization of the Spring River basin, southwestern Missouri and southeastern Kansas. United States Geological Survey Water Resources Investigations Report 90-4176. United States Geological Survey, Rolla

Dillman CB, Wagner BK, Wood RM (2010) Phylogenetic estimation of species limits in dwarf crayfishes from the Ozarks, Orconectes macrus and Orconectes nana (Decapoda: Cambaridae). Southeast Nat 9(sp3): 185-198

DiStefano RJ (2005) Trophic interactions between Missouri Ozarks stream crayfish communities and sport fish predators-increased abundance and size structure of predators cause little change in crayfish community densities. Project F-1-R-054, Study S-41, Job 4, Final report. Missouri Department of Conservation, Columbia 
DiStefano RJ, Decoske JJ, Vangilder TM, Barnes LS (2003) Macrohabitat partitioning among three crayfish species in two Missouri streams, USA. Crustaceana 76:343-362

DiStefano RJ, Herleth-King SS, Imhoff EI (2008) Distribution of the imperiled Meek's crayfish (Orconectes meeki meeki, Faxon) in the White River drainage of Missouri, USA - associations with multi-scale environmental variables. Freshw Crayfish 16:27-36

Farag AM, Woodward DF, Brumbaugh WG, Goldstein JG, MacConnell E, Hogstrand C et al (1999) Dietary effects of metalscontaminated invertebrates from the Coeur d'Alene River, Idaho, on cutthroat trout. Trans Am Fish Soc 128:578-592

Flinders CA, Magoulick DD (2003) Effects of stream permanence on crayfish community structure. Am Midl Nat 149(1):134-147

Flinders CA, Magoulick DD (2005) Distribution, habitat use, and life history of stream-dwelling crayfish in the Spring River drainage of Arkansas and Missouri with a focus on the Mammoth Spring crayfish (Orconectes marchandi). Am Midl Nat 154:358-374

Gore JA, Bryant RM Jr (1990) Temporal shifts in physical habitat of the crayfish, Orconectes neglectus (Faxon). Hydrobiologia 199:131-142

Hill AM, Lodge DM (1995) Multi-trophic-level impact of sublethal interactions between bass and omnivorous crayfish. J N Am Benthol Soc 14:306-314

Hobbs HH Jr (1993) Trophic relationships of North American freshwater crayfishes and shrimps. Milwaukee Public Museum, Milwaukee

Ingersoll CG, MacDonald DD, Wang $\mathrm{N}$, Crane JL, Field LJ, Haverland PS et al (2001) Predictions of sediment toxicity using consensus-based freshwater sediment quality guidelines. Arch Environ Contam Toxicol 41(1):8-21

Knowlton MF, Boyle TP, Jones JR (1983) Uptake of lead from aquatic sediment by submersed macrophytes and crayfish. Arch Environ Contam Toxicol 12(5):535-541

Lodge DM, Hill AM (1994) Factors governing species composition, population size, and productivity of cool-water crayfish. Nord J Freshw Res 69:111-136

MacDonald DD, Ingersoll CG, Berger TA (2000) Development and evaluation of consensus-based sediment quality guidelines for freshwater ecosystems. Arch Environ Contam Toxicol 39: 20-31

MacDonald DD, Ingersoll CG, Crawford M, Prencipe H, Besser JM, Brumbaugh WG et al (2010) Advanced screening-level ecological risk assessment (SLERA) for aquatic habitats within the TriState Mining District, Oklahoma, Kansas, and Missouri. Draft Final Technical Report submitted to the United States Environmental Protection Agency, Region 6, Dallas, Texas, Region 7, Kansas City, Kansas, and the United States Fish and Wildlife Service, Columbia

Magoulick DD, DiStefano RJ (2007) Invasive crayfish Orconectes neglectus threatens native crayfishes in the Spring River drainage of Arkansas and Missouri. Southeast Nat 6(1):141-150

Maret TR, MacCoy DE (2002) Fish assemblages and environmental variables associated with hardrock mining in the Coeur d'Alene river basin, Idaho. Trans Amer Fish Soc 131:865-884

May TW, Wiedmeyer RH, Brumbaugh WG, Schmitt CJ (1997) The determination of metals in sediment pore waters and in $1 \mathrm{~N} \mathrm{HCl}-$ extracted sediments by ICP-MS. At Spectrosc 18:133-139

Mitchell DJ, Smock LA (1991) Distribution, life history and production of crayfish in the James River, Virginia. Am Midl Nat 126(2):353-363

Momot WT (1995) Redefining the role of crayfish in aquatic ecosystems. Rev Fish Sci 3:33-63

Momot WT, Gowing H, Jones PD (1978) The dynamics of crayfish and their role in ecosystems. Am Midl Nat 99(1):10-35

Pfleiger WL (1996) The crayfishes of Missouri. Missouri Department of Conservation, Jefferson
Rabalais MR, Magoulick DD (2006) Influence of an invasive crayfish species on diurnal habitat use and selection by a native crayfish species in an Ozark stream. Am Midl Nat 155:295-306

Rabeni CF (1985) Resource partitioning by stream-dwelling crayfish - the influence of body size. Am Midl Nat 113:20-29

Rabeni CF, Gossett M, McClendon DD (1995) Contribution of crayfish to benthic invertebrate production and trophic ecology of an Ozark stream. Freshw Crayfish 10:163-173

Schmitt CJ, Wildhaber ML, Hunn JB, Nash T, Tieger MN, Steadman BL (1993) Biomonitoring of lead-contaminated Missouri streams with an assay for erythrocyte $\delta$-aminolevulinic acid dehydratase activity in fish blood. Arch Environ Contam Toxicol $25: 464-475$

Schmitt CJ, Brumbaugh WG, Linder GL, Hinck JE (2006) A screening-level assessment of lead, cadmium, and zinc in fish and crayfish from northeastern Oklahoma, USA. Environ Geochem Health 38:445-471

Schmitt CJ, Brumbaugh WG, Besser JM, Hinck JE, Bowles DE, Morrison LW et al (2008) Protocol for monitoring metals in Ozark National Scenic Riverways, Missouri, Version 1.0. United States Geological Survey Open-File Report 2008-1269. http://pubs.usgs.gov/of/2008/1269/. Accessed 14 May 2009

Stein RA, Magnuson JJ (1976) Behavioral response of crayfish to a fish predator. Ecology 57(4):751-761

Stewart DR (1986) A brief description of the historical, ore production, mine pumping, and prospecting of the Tri-State Zinc-Lead District of Missouri, Kansas, and Oklahoma. In: Hagni RD (ed) Guidebook to the geology and environmental concerns in the Tri-States Lead-Zinc District, Missouri, Kansas, Oklahoma. Division of Geology and Land Survey-Department of Natural Resources, Department of Geology and Geophysics, University of Missouri-Rolla, Rolla, pp 16-29

Strahler AN (1952) Dynamic basis of geomorphology. Geol Soc Am Bull 63:305-923

United States Environmental Protection Agency (1992) Framework for ecological risk assessment. EPA-630-R-92-001. USEPA, Washington DC

United States Environmental Protection Agency (1993) Wildlife exposure factors handbook. EPA-600-R-93-187. USEPA, Washington DC

United States Environmental Protection Agency (1997) Ecological risk assessment guidance for Superfund-process for designing and conducting ecological risk assessments. EPA-540-R-97-006. USEPA, Washington DC

United States Environmental Protection Agency (1999) Screening level ecological risk assessment protocol for hazardous waste combustion facilities. Peer draft review, v. 1. EPA-530-D-99001A. USEPA, Washington DC

United States Environmental Protection Agency (2005) Procedures for the derivation of equilibrium partitioning sediment benchmarks (ESBs) for the protection of benthic organisms: Metal mixtures (cadmium copper, lead nickel, silver, and zinc). EPA600-R-Q2-011, USEPA, Office of Research and Development, Washington DC

United States Environmental Protection Agency (2006) National recommended water quality criteria, updated 2009. http://www. epa.gov/waterscience/criteria/wqctable/index.html. Accessed 15 May 2009

United States Environmental Protection Agency, Office of Solid Waste and Emergency Response (2007) Ecological soil screening levels for nickel. Interim final OSWER directive 9285.7-76. http://www.epa.gov/ecotox/ecossl/pdf/eco-ssl_nickel.pdf. Acces sed 15 May 2009

Vannote RL, Minshall GW, Cummins KW, Sedell JR, Cushing CE (1980) The river continuum concept. Can J Fish Aquat Sci $37: 130-137$ 
Wang N, Ingersoll CG, Ivey CD, Hardesty DK, May TW, Augspurger $T$ et al (2010) Sensitivity of early life stages of freshwater mussels (Unionidae) to acute and chronic toxicity of lead, cadmium, and zinc in water. Environ Toxicol Chem 29:2053-2063

Westhoff JT, Guyot JA, DiStefano RJ (2006) Distribution of the imperiled Williams' crayfish (Orconectes williamsi) in the White River drainage of Missouri-associations with multi-scale environmental variables. Am Midl Nat 156(2):273-288

Wigginton AJ, Birge WJ (2007) Toxicity of cadmium to six species in two genera of crayfish and the effect of cadmium on molting success. Environ Toxicol Chem 26:548-554

Wildhaber ML, Schmitt CJ (1996) Estimating aquatic toxicity as determined through laboratory tests of Great Lakes sediments containing complex mixtures of environmental contaminants. Environ Monit Assess 41:255-289
Wildhaber ML, Schmitt CJ, Allert AL (1997) Elemental concentrations in benthic invertebrates from the Neosho, Cottonwood, and Spring rivers. Final report to the United States Fish and Wildlife Service, Region 6, Manhattan, Kansas. United States Geological Survey, Columbia

Wildhaber ML, Allert AL, Schmitt CJ, Tabor VM, Mulhern D, Powell KL et al (2000) Natural and anthropogenic influences on the distribution of the threatened Neosho madtom in a midwestern warmwater stream. Trans Am Fish Soc 129:243-261

Williams AB (1952) Six new crayfishes of the genus Orconectes (Decapoda: Astacidae) from Arkansas, Missouri and Oklahoma. Trans Kans Acad Sci 55(3):330-351

Zhang Y, Richardson JS, Negishi JN (2004) Detritus processing, ecosystem engineering and benthic diversity-a test of predatoromnivore interference. J Anim Ecol 73:756-766 